Ю.О. Фтемов

Національна академія сухопутних військ ім. гетьмана П. Сагайдачного, Львів

\title{
РЕКОМЕНДАЦІЇ ЗІ СТВОРЕННЯ СПЕЦІАЛІЗОВАНОГО ПРОГРАМНОГО ЗАБЕЗПЕЧЕННЯ ДЛЯ РОЗРАХУНКУ СИСТЕМИ ІНЖЕНЕРНИХ ЗАГОРОДЖЕНЬ
}

У статті проведено загальний аналіз характеру та особливостей сучасних оборонних операцій (бойових дій), ролі та місия системи інженерних загороджень і способів розрахунку ї складових елементів з урахуванням досвіду збройних сил країн-членів НАТО щздо планування влаштування інженерних загороджень у відповідності до етапів процесу прийняття рішення. Обгрунтовано $і$ запропоновано рекомендації щзодо створення спеціалізованого програмного забезпечення із розрахунку та планування системи інженерних загороджень в ході оборонного бою (операціï).

Ключові слова: система інженерних загороджень, оборона, ефективність інженерних загороджень, спеціалізоване програмне забезпечення, прочес планування.

\section{Вступ}

Постановка проблеми. У відповідності до стратегічних цілей, низки керівних документів, які регламентують функціонування і розвиток Збройних Сил (3С) України, ключовим завданням є удосконалення системи управління. Вирішення якого можливо шляхом створення єдиної інформаційної системи управління оборонними ресурсами.

Враховуючи особливості ведення збройної боротьби в сучасних умовах, необхідно виділити основне протиріччя у сфері управління військами - між зростаючими обсягами інформації та зменшенням часу, що є в наявності в органів управління для ii збору, обробки і доведенням до командувача (командирів) необхідної інформації з метою прийняття раціонального, обгрунтованого рішення [1].

Розв'язання цього протиріччя полягає у значному підвищенні оперативності процесу збору, обробки і доведенні інформації, що забезпечить підвищення оперативності управління в цілому [2].

Аналізуючи ведення локальних війн і збройних конфліктів останніх років, слід зазначити, що відбуваються значні зміни в теорії інженерної підтримки сучасних бойових дій. Чільне місце при цьому займає створення, перш за все, ефективної системи інженерних загороджень (СI3). Однак, питанням автоматизованого управління, а особливо плануванню зі створення СІ3, у загальній системі, належної уваги не приділено. Існуючі розрахункові програми $\epsilon$ достатньо оперативними, поряд 3 тим вони вирішують математичні задачі окремих інженерних заходів та потребують систематизації.

Аналіз останніх досліджень і публікацій. Грунтуючись на проведеному аналізі [1-3] можна зробити висновок, що рівень автоматизації діяльності органів управління становить лише близько $30 \%$ від потреб, наявні системи, засоби не складали цілісних систем, існуючі інформаційно-розрахункові задачі відповідали потребам пунктів управління лише на $15 \%$, у зв'язку з чим керівному складу для вироблення та прийняття рішень залишалося тільки 17\% часу від циклу управління на відміну від 75-80\%, що $є$ характерним для збройних сил передових країн світу.

Досвід проведення ООС показує, що практично відсутність цілісної системи автоматизованого управління військами дуже суттєво знижує ступінь реалізації бойових можливостей військ (сил).

Вивчаючи джерела [4-5], у яких започатковано вирішення даної проблеми щодо удосконалення автоматизації планування СI3 в керівних документах, розкрито не в повному обсязі, що у свою чергу спонукає до опрацювання відповідних рекомендацій.

Наявний науково-методичний апарат базується на положеннях, які розроблялися авторами [5-8], та безумовно враховує загальні підходи та способи виконання розрахункових завдань СІ3. Разом з тим, отримані результати можуть бути адаптовані умовам, що висуваються, лише частково.

Мета статті. Враховуючи наведене вище, а також те, що обгрунтування вимог до основних напрямків розвитку автоматизованого планування зі створення СІ3 вирішено лише у вигляді окремих завдань (заходів), метою статті є висвітлення підходу щодо формування вимог до оптимізації процесу планування CI3, які можуть бути реалізовані за допомогою методів оптимізації, а саме через програмне (математичне) моделювання.

\section{Виклад основного матеріалу}

Основні зусилля, як вітчизняних так і західних воєнних аналітиків зосереджені на прогнозуванні не стільки локальних, скільки великомасштабних війн. Розглядаються різні їх моделі з перспективою на 20- 
25 років, щоб визначити оптимальні довгострокові програми, зробити замовлення на новітнє озброєння, цілеспрямовано готувати організаційні структури збройних сил до майбутнього протистояння [9].

Війни, які пройшли, переконливо показали, що технічна перевага у зброї однієї сторони здатна звести нанівець кількісну перевагу іншої сторони в силах та застарілих озброєннях і вимагає вести воєнні дії зовсім по іншому, ніж це уявлялось раніше.

До особливостей сучасних операцій (бойових дій) слід віднести: відсутність суцільної лінії та дій на широкому фронті; обмеженість чисельності сил і засобів для виконання завдань; значне збільшення глибини ешелонування угруповання військ (сил); наявність значних проміжків (відстаней) в оперативній побудові; виконання в ході операцій широкого спектра завдань, спрямованих на ізоляцію району збройного конфлікту, боротьбу 3 диверсійнорозвідувальними силами противника та незаконними збройними формуваннями; охорону важливих об’єктів і комунікацій, охорону та супроводження колон; обмеження щодо застосування засобів вогневого ураження, МВ3, ведення бойових дій у населених пунктах та ведення рейдових дій [10].

Успішне ведення противником наступальних бойових дій забезпечується своєчасною доставкою на поле бою підрозділів, бойової техніки і матеріально-технічних засобів, а також інженерною підтримкою подолання ними перешкод і загороджень, тобто забезпечення мобільності військ [10].

Для вирішення цього завдання будуть залучатись значні сили не тільки інженерних, але й інших родів військ. Тому комплекс завдань 3 мобільності військ буде включати: протимінну боротьбу; розвідку мінних полів (МП), влаштування в них проходів; позначення МП і їх розмінування; подолання перешкод - застосування засобів інженерного озброєння для влаштування мостових переходів через перешкоди та пророблення проходів в інженерних загородженнях або обладнання обходів; форсування водних перешкод; підготовку та утримання доріг і колонних шляхів [5].

Виходячи 3 цього, особливої актуальності набувають питання підготовки військ до проведення перших оборонних операцій початкового періоду війни та їх інженерної підтримки з подальшим переходом у контрнаступ.

Успіх організації інженерної підтримки сучасних оборонних операцій базується на твердому знанні і глибокому розумінні основ їх підготовки i ведення, змісту, видів, способів і форм воєнних дій. При цьому основою інженерної підтримки оборонної операції (бою) буде успішно спланована та своєчасно створена СІ3.

Слід зазначити, що планування СІ3 в оборонній операції здійснюється в тісному поєднанні з ВУП, яке в залежності від умов обстановки і дій противника може включати: вогневу контрпідготовку; вогневу заборону висування і розгортання військ противника; вогневе відбиття атаки противника; вогневу підтримку військ, що обороняються, у глибині; ВУП при нанесенні контратак і контрударів [11].

3 урахуванням цього в системі загороджень можна виділити: загородження на підступах до оборони; загородження в смузі забезпечення, загородження перед переднім краєм головної смуги оборони, у проміжках і на флангах частин (підрозділів) на глибину районів оборони батальйонів, а іноді і смуг оборони бригад першого ешелону; загородження в глибині оборони [12].

Необхідно відмітити, що будь-яка система, в тому числі і CI3, може бути створена і успішно функціонувати при наявності необхідних сил і засобів. Запорукою успішного функціонування СI3 $є$ відповідність можливостей сил і засобів по виконанню завдань щодо іiі створення необхідним завданням, які забезпечують належну ефективність останньої. Шляхом вирішення цього питання можливо лише при наявності відповідного методикоматематичного апарату щодо оцінки ефективності СІ3 при веденні оборонної операції (бою) [13].

Проведений аналіз свідчить, що існує значна кількість способів з розрахунку всіх складових елементів СІ3 та оцінювання iіi ефективності в цілому [4; 6-8]. Широкого використання набули наступні способи: аналітичний, графічний та схематичнотабличний.

Аналітичний спосіб застосовується для розрахунку кількості сил і засобів для створення СІ3 по заданому вкладу інженерних загороджень у ВУП (визначеним щільностями інженерних загороджень) та на ї основі визначення коефіцієнта затримки противника, або проведення зворотних розрахунків - виходячи $з$ наявних сил, засобів та часу на створення СI3, розрахунок вкладу та щільності, яка досягається. Даний спосіб є більш точним, однак потребує значної кількості часу. Другий та третій способи застосовуються для проведення оперативних розрахунків в умовах обмеженого часу. При цьому, схематично-табличний спосіб використовують, як правило, в органах управління тактичної ланки.

Таким чином, аналіз способів (методик), які використовуються для розрахунку СІ3, вказує на достатньо складні їх структури, є досить об'ємними і потребують значного часу. Досвід навчань свідчить, що робота особи, яка здійснює планування створення СІ3 значно полегшується, якщо при цьому використовуються формалізовані документи, які розроблені завчасно, засоби автоматизації проведення розрахунків, тощо.

Відповідно, напрямами зменшення часу та підвищення якості виконання робіт щодо вироблення 
рішення буде подання у формалізованій формі та автоматизація за допомогою ПЕОМ проведення розрахунків на етапі усвідомлення завдання, оцінювання обстановки та безпосередньо визначення складових рішення, що приймається в ході планування створення СІ3.

Одним із варіантів вирішення зазначеного вище $\epsilon$ удосконалення методичного апарату шляхом створення спеціалізованого програмного забезпечення (СПЗ) для розрахунку СІ3, яке базуватиметься на основі сукупності способів (методик), що розглядалися [14]. Іншими словами - програмного продукту, який в подальшому повинен стати невід'ємною складовою єдиної автоматизованої системи управління військами [15].

За усталеним визначенням управління - це процес цілеспрямованого впливу командирів, штабів на війська, що здійснюється для підтримки готовності військ до виконання завдань за призначенням, їх підготовки та успішного виконання ними завдань у ході ведення операції (бойових дій).

Слід зазначити, що однією із складових мети управління військами $є$ забезпечення визначеного рівня бойової готовності військ, їх всебічна підготовка до застосування та ефективна реалізація оперативних (бойових) можливостей військ у ході ведення операцій (бойових дій). Тому досягнення зазначеної вище мети можливо здійснити через процес оптимізації, як системи управління в цілому, так і зокрема ії складових.

На сьогодні заслуговує уваги навчальна автоматизована система управління військами “Славутич”, яка активно впроваджена та використовується у Національному університеті оборони України. В ній автоматизовані процеси управління, які мають місце на всіх етапах і фазах оперативного планування та ведення операції (бою). Однак іiї інформаційно-розрахункова підсистема націлена на вирішення лише окремих завдань (заходів) із розрахунку СI3.

3 метою забезпечення успішного функціонування програмного продукту СІ3 створюється багаторівнева база даних до якої входять: часові показники, основні завдання (заходи) інженерної підтримки, детальні відомості про сили, засоби, як противника, так і про свої війська тощо [13-14].

Загальний алгоритм роботи СПЗ являє собою ряд взаємопов'язаних деталізованих інструкцій, що реалізують процес обчислення, який, починаючи 3 початкового стану, відбувається через послідовність логічних станів та завершується кінцевим. Перехід 3 попереднього до наступного стану не обов'язково детермінований - деякі алгоритми можуть містити елементи випадковості.

При введені інформації (завдань, окремих заходів), для прикладу з контрмобільності підрозділів противника: кінцевим результатом обчислення $є$ формування висновку щодо можливостей (спроможностей) своїх підрозділів виконати визначене бойове завдання.

Важливим етапом формування вихідних даних $\epsilon$ цифрове відображення на дисплеї планшета (ПЕОМ) детальної обстановки, що склалася, відомостей про противника та свої війська, особливо про їх інженерні заходи. Далі, відповідно до замислу (рішення) загальновійськового командира, на цифровій карті (схемі) виводяться задані щільності інженерних загороджень (ефекти), яких повинні будуть спочатку досягти на етапі планування CI3.

Враховуючи те, що стратегічною метою України у секторі безпеки та оборони є інтеграція у євроатлантичний безпековий простір, передусім до Організації Північноатлантичного договору, саме тому частиною цього процесу є реформування 3С України відповідно до принципів та стандартів НАТО.

Впродовж останніх років у рамках спільних навчань ЗС України із партнерами по НАТО, наголос було перенесено саме на планування і ведення операцій відповідно до практики Північноатлантичного альянсу. Новий фокус навчань дає можливість українській стороні на практиці опановувати алгоритми дій НАТО в різних аспектах, тим самим посилюючи взаємосумісність і реалізуючи на практиці ціль щодо інтеграції до Альянсу.

Слід зазначити, що командири усіх рівнів країн-членів НАТО включають планування влаштування інженерних загороджень до кожного етапу процесу прийняття рішення. Це гарантує, що поєднання загороджень буде ефективним, план буде досить гнучким до змін під час планування, підготовки і виконання етапів операції. Планування зі створення перешкод на рівні оперативної групи грунтується на доктрині, яка наведена в FM 101-5, а для бригади і вищих рівнів розкрито в FM 90-7 [16-17].

Планування оборони на рівні оперативної групи є частиною військового процесу прийняття рішення. Інженерний аналіз поля бою (EBA) забезпечує базу даних для узгодження заходів інженерної підтримки 3 процесом прийняття рішення. Де на етапі аналізу завдання є: визначення фактів і припущень; аналіз боєздатності підрозділів; аналіз завдання підрозділів та замисел командира; відпрацювання наказу командира.

Початком планування оборони є одержання попереднього наказу (WO) із вищого штабу. Це $\epsilon$ основою для створення моделі ситуації (SITEMP), яка включає модифіковану схему комбінованих загороджень (МСОО). МСОО є продуктом, розробленим на підставі розвідки поля бою (IPB) та є спільною роботою інженерів і офіцерів розвідки центру тактичних операцій (ТОС).

Одним із важливих кроків роботи інженера в ході етапу планування є проведення аналізу: місце- 
вості (підготовка оверлею на брифінг), погодних умов, інших факторів, що впливатимуть на виконання завдань [18].

При вивченні військового аспекту місцевості основна увага приділяється наступним двом складовим, так званим OAKOC: Observation and fields of fire (оглядовість та зони вогню), Avenues of approach (шляхи для маневру), Key and decisive terrain (ключові і важливі ділянки місцевості); Obstacles (перешкоди), Cover and concealment (укриття та маскування); та ASCOPE: Area (район), Structures (структура), Capabilities (можливості), Organizations (організаціi), People (люди), Events (подіi).

Основні зусилля зосереджуються на: підготовці до ЕЕР (карти, довідкові дані, тощо), оцінюванні можливостей з інженерної підтримки (часові показники, сили і засоби, можливості інженерних підрозділів), завданні старшого начальника, меті (2, 1 рівень вище), замислі бою (дій) старшого начальника (зрозуміти головну ідею), task organization (attachments/dettachments, сили і засоби), матеріально-технічному забезпеченні (restrictions from logistic, deliveries of assets), розробленні плану інженерної підтримки.

На початковому етапі здійснюється підготовка “інженерного оверлею” (наносяться межі, положення противника), АО (зона ведення бою (дій) - місцевість, на якій командир уповноважений на ведення бою (дій). Визначаються межі зони ведення бою (дій), AI (зона інтересів - місцевість, на якій необхідно вести розвідку для якісного планування бою (дій) та забезпечення успіху дій старшого начальника.

Отже, використання наведеного способу можливо шляхом поєднання основних результатів відпрацювання “інженерного оверлею” та електронній дошці (екрані) з подальшим відображенням на дисплеї, як загальної обстановки, так і “інженерної обстановки".

У подальшому СІ3 формується шляхом нанесення на цифрову карту по елементах різноманітних інженерних загороджень з урахуванням “доступності” для дій військ противника. Програма дає можливість при збільшенні (зменшенні) форми об'єкта, отримувати відомості про його протяжність, глибину, витрату боєприпасів, ймовірність ураження, час затримання тощо. При цьому оператором обов'язково задаються такі відомості як: ефект загородження, тип боєприпасів, спосіб виконання завдання, сили, засоби механізації, умови виконання та ін. [19-20].

Результатом опрацювання наведених вище даних $є$ надання пропозицій щодо спроможності підрозділу виконати визначене завдання, потреба у додатковому оснащенні засобами, пропонується схема улаштування загородження для досягнення заданого ефекту, а також визначаються щільність загороджень їх координати, які у свою чергу доповнюють базу додаткових можливостей програми. До них належить: внесення відомостей до "Е-формуляру" загороджень, коригування їх у ході проведення рекогносцирувальних робіт, передача інформації до вищих штабів, а також внесення змін у ході виконання завдань в умовах реального часу тощо.

Важливе місце на даному етапі займає саме відпрацювання та оформлення звітних документів 3 обліку, як окремих загороджень, так СІЗ в цілому.

Слід зазначити, що на початковій фазі проведення АТО на Сході України інженерні загородження в повному обсязі не використовувались, тим більше не об'єднувались у певну систему. В першу чергу це було обумовлено постійною зміною бойової обстановки та відповідно бойового порядку сил та засобів секторів, відсутністю належного забезпечення інженерними боєприпасами та недосконалими заходами прикриття державного кордону. Крім того інженерні загородження своєчасно не обліковувались, формуляри складалися із запізненням, а при ротації (зміні) підрозділів передавились з порушенням керівних вимог $[4 ; 21]$.

Також необхідно зазначити, що в ході передачі даних $з$ одного рівня до основної бази даних, оператором вводяться умови ведення бою (операції) 3 обов'язковим врахуванням різноманітних коефіцієнтів, серед яких чільне місце займає "коефіцієнт реальності”, який враховує поступове зменшення можливостей підрозділів. Після чого на інтерфейс користувача виводиться інформація про витрату засобів інженерного озброєння, майна, визначається потреба у машинорейсах, пальному тощо.

На основі опрацювання усіх даних визначається бойова ефективність інженерних загороджень, яка характеризується наступними кількісними показниками як: ураження техніки, живої сили, а також зменшення темпу просування противника та ін.

Результатом обробки даних на завершальному етапі, є формування ряду пропозицій, які надаються на затвердження старшому командиру (начальнику).

Також, у разі виявлення обмежених можливостей підрозділів з виконання завдань по створенню СІ3 (визначених щільностей), передбачено функцію щодо додаткового залучення необхідних сил і засобів старшого начальника. При підтвердженні запиту, вони вносяться до загальної бази даних.

Після затвердження командиром пропозицій, наданих начальником інженерної служби (відділу групи), здійснюється їх доведення до підпорядкованих підрозділів через систему засобів комунікації.

Слід зазначити, що даним питанням у збройних силах держав-членів Північноатлантичного альянсу приділяється значна увага протягом тривалого періоду часу. Заслуговує уваги ряд розрахункових про- 
грам типу “Engineer asset calculation”, “ЕС” та ін., які спрощують процес планування операцій офіцерами штабу НАТО на відміну від роботи офіцерів штабу ЗС України.

Враховуюче те, що СІ3 в побудові оборони є одним із важливих піi елементів. При цьому роль і вагомість СІ3 в сучасних умовах постійно зростає. Це обумовлено невідповідністю просторового розмаху ведення бойових дій і наявними силами (засобами), що приймають в ній участь, а також невідповідністю обсягів завдань із створення СІ3 і можливостям військ по іiі створенню. Тому питання оперативності та своєчасності вироблення рішення, доведення до підрозділів, уточнення і врахування інтенсивності змін будуть запорукою успішності ведення бойових дій військ (сил) [11].

Отже, автоматизація процесу планування i управління СI3, який базуватиметься на основі створення СПЗ для іï розрахунку, вкотре підтверджує актуальність і практичне значення роботи.

\section{Висновки}

Таким чином, впровадження рекомендацій щодо розроблення СПЗ, дозволить скоротити час на проведення розрахунків до $25 \%$, а також підвищить кількість можливих варіантів створення СІ3.

Одним із подальших напрямків проведення досліджень є системний захист передачі інформації в інформаційно-комунікаційній мережі в умовах реального часу та її вдосконалення.

\section{Список літератури}

1. Гаценко С.С. Аналіз вимог до систем управління військами та шляхи їх удосконалення / С.С. Гаценко // Збірник наукових праць Центру воєнно-стратегічних досліджень Національного університету оборони України ім. І. Черняховського. - 2015. - № 2(54). - С. 85-90.

2. Гумінський Р.В. Автоматизація діяльності командира, штабу при прийнятті рішень на операцію (бойові дії)/ Р.В. Гумінський, Є.В. Рижов, О.В. Корольова // Військово-технічний збірник національної академії сухопутних військ ім. гетьмана П. Сагайдачного. - 2010. - № 3. - С. 75-81. https://doi.org/10.33577/2312-4458.3.2010.75-81.

3. Гаценко С.С. Методика оцінювання оперативної обстановки в автоматизованих системах управління військами в умовах невизначеності / С.С. Гаценко // Наука і техніка Повітряних Сил Збройних Сил України. - 2017. - № 1(26). C. 101-105. https://doi.org/10.30748/nitps.2017.26.21.

4. Наказ Міністра оборони України “Керівництво з улаштування інженерних загороджень підрозділами Міністерства оборони України та Збройних Сил України № 330 від 10.07.2015”.

5. Нещадін О.В. Інженерне забезпечення бою в сучасних операціях / О.В. Нещадін, О.Й. Мацько, Ю.О. Фтемов. Львів: НАСВ, 2017. - 320 с.

6. Оперативні розрахунки завдань інженерного забезпечення. Методики та приклади / В.I. Коцюруба, I.B. Черних, О.Й. Мацько, М.М. Підгородецький. - К.: НУОУ, 2016. - 152 с.

7. Каршень А.М. Методика інженерних розрахунків виконання інженерних завдань / А.М. Каршень, О.Л. Колос, О.М. Галушка. - Л.: НАСВ, 2020. - 184 с.

8. Нещадін О.В. Методика інженерно-тактичних розрахунків під час прийняття рішення / О.В. Нещадін, М.О. Івасюк, Ю.О. Фтемов. - Л.: НАСВ, 2019. - 310 с.

9. Хомчак Р.Б. Метод визначення оптимальних внесків видів (родів) військ в успішне вирішення ними бойових завдань $з$ встановленою величиною відверненого збитку за умови мінімізації необхідних для цього затрат / Р.Б. Хомчак // Військово-технічний збірник національної академії сухопутних військ ім. гетьмана П. Сагайдачного. - 2020. - № 23. C. 86-90. https://doi.org/10.33577/2312-4458.23.2020.

10. Фтемов Ю.О. Ймовірні варіанти розв'язання війни і погляди на ведення наступу з подоланням інженерних загороджень / Ю.О. Фтемов // Збірник тез доповідей ІІІ Міжнародної науково-практичної конференції “Сучасні проблеми забезпечення національної безпеки держави”. - Київ, 26 листопада 2020 р. - С. 124-126.

11. Фтемов Ю.О. Рекомендації з прикриття міжпозиційного простору із урахуванням заходів завчасної підготовки території до оборони / Ю.О. Фтемов // Системи озброєння і військова техніка. - 2020. - № 4(64). - С. 43-48. https://doi.org/10.30748/soivt.2020.64.05.

12. Фтемов Ю.О. Організаційні і підготовчі заходи зі створення системи інженерних загороджень / Ю.О. Фтемов // Збірник тез доповідей XII Всеукраїнської науково-практичної конференції “Освітньо-наукове забезпечення діяльності складових сектору безпеки й оборони України”. - Хмельницький, 26 листопада 2020 р. - С. 967-970.

13. Фтемов Ю.О. Рекомендації зі створення спеціалізованого програмного забезпечення для розрахунку системи інженерних загороджень / Ю.О. Фтемов // Збірник тез доповідей ХІІІ науково-практичної конференції “Пріоритетні напрямки розвитку телекомунікаційних систем та мереж спеціального призначення. Застосування підрозділів, комплексів, засобів зв’язку та автоматизації в Операції об'єднаних сил”. - Київ, 3-4 грудня 2020 р. - С. 277-279.

14. Фтемов Ю.О. Спеціалізоване програмне забезпечення для розрахунку системи інженерних загороджень / Ю.О. Фтемов // Збірник матеріалів науково-практичної конференції “Інформаційно-телекомунікаційні системи і технології та кібербезпека: нові виклики, нові завдання”. - Київ, 18-19 листопада 2020 р. - С. 195-197.

15. Фтемов Ю.О. Рекомендації з прикриття міжпозиційного простору / Ю.О. Фтемов // Збірник тез доповідей науково-практичної конференції “Застосування Сухопутних військ Збройних Сил України у конфліктах сучасності”. Львів, 20 листопада 2020 р. - С. 200-201.

16. FM 101-5. Staff organization and operations [Electronic resource]. - Washington: DC, 1997. - 267 c. - Available at: 
https://www.globalsecurity.org/military/library/policy/army/fm/101-5/f540.pdf.

17. FM 90-7. Combined arms obstacle integration [Electronic resource]. - Washington: DC, 2003. - 178 c. - Available at: https://www.globalsecurity.org/military/library/policy/army/fm/90-7/fm90-7_c1_2003.pdf.

18. FM 3-34. Engineer operations [Electronic resource]. - Washington: DC, 2011. - 118 c. - Available at: https://www.globalsecurity.org/military/library/policy/army/fm/3-34/fm3_34_2011.pdf.

19. Фтемов Ю.О. Ефекти мінних полів / Ю.О. Фтемов // Збірник тез доповідей науково-технічної конференції “Перспективи розвитку озброєння та військової техніки сухопутних військ”. - Львів, 14-15 травня 2018 р. - 158 с.

20. Бамбуляк М.П. Улаштування інженерних загороджень в особливих умовах [Електронний ресурс] / М.П. Бамбуляк, Ю.О. Фтемов, Р.Л. Колос // Системи озброєння і військова техніка. - 2014. - № 1(37). - С. 2-4. - Режим доступу: http://www.hups.mil.gov.ua/periodic-app/article/2305/soivt_2014_1_3.pdf.

21. Фтемов Ю.О. Способи підвищення бойових можливостей інженерних боєприпасів / Ю.О. Фтемов, Р.Л. Колос, В.П. Павлючик // Військово-технічний збірник Академії сухопутних військ ім. гетьмана П. Сагайдачного. - 2016. № 15. - C. 58-62. http://nbuv.gov.ua/UJRN/vtzb_2016_15_13.

Надійшла до редколегії 02.02.2021

Схвалена до друку 02.03.2021

\section{Відомості про автора:}

\section{Фтемов Юрій Олександрович}

кандидат технічних наук старший науковий співробітник доцент кафедри Національної академії сухопутних військ ім. гетьмана П. Сагайдачного, Львів, Україна https://orcid.org/0000-0003-1709-5395

\section{Information about the author:}

\author{
Yuriy Ftemov \\ Candidate of Technical Sciences \\ Senior Research \\ Senior Lecturer of Department \\ of Hetman Petro Sahaidachnyi National Army Academy, \\ Lviv, Ukraine \\ https://orcid.org/0000-0003-1709-5395
}

\section{РЕКОМЕНДАЦИИ ПО СОЗДАНИЮ СПЕЦИАЛИЗИРОВАННОГО ПРОГРАММНОГО ОБЕСПЕЧЕНИЯ ДЛЯ РАСЧЕТА СИСТЕМЫ ИНЖЕНЕРНЫХ ЗАГРАЖДЕНИЙ}

Ю.А. Фтемов

В статье проведен общий анализ характера и особенностей современных оборонных операџии (боевых действий), роли и места системы инженерных заграждений и способов расчета ее составляющих элементов с учетом опыта вооруженных сил стран-членов НАТО по планированию устройства инженерных заграждений в соответствии с этапами процесса принятия решения. Обоснованно и предложены рекомендации по созданию специализированного программного обеспечения по расчету и планирования системы инженерных заграждений в ходе оборонительного боя (операчии).

Ключевые слова: система инженерных заграждений, оборона, эффективность инженерных заграждений, специиализированное программное обеспечение, процесс планирования.

\section{RECOMMENDATIONS FOR CREATING SPECIALIZED SOFTWARE FOR CALCULATION THE ENGINEERING BARRIER SYSTEMS}

\section{Yu. Ftemov}

The experience of fighting in the East of Ukraine shows that there is no integrated system of automated control of troops significantly reduces the degree of realization of combat capabilities of the troops (forces). Given the fact that in recent years there have been significant changes in the theory of engineering support of fighting. In turn, this is due to the inconsistency of the spatial scope of hostilities and the available forces (means) participating in it, as well as the inconsistency of the scope of tasks to create a system of engineering barriers to the capabilities of troops. However, the issue of automated control, and especially planning for the creation of a system of engineering barriers, in the general system of automated control of troops, is not given due attention. Existing calculation programs are quite operational, at the same time they solve mathematical problems of individual engineering activities and need to be systematized. Therefore, the article considers approaches to the formation of requirements for the optimization of the planning process of the system of engineering barriers, which can be implemented based on optimization methods, namely through the creation of specialized software. The general algorithm of specialized software is a series of interconnected detailed instructions that implement the calculation process, which, starting from the initial state, occurs through a sequence of logical states and ends with the final one. The transition from the previous to the next state is not necessarily deterministic - some algorithms may contain elements of randomness. When entering information (tasks, individual measures), for example, the counter ability of enemy units: the result of the calculation is to form a conclusion about the capabilities of their units to perform a specific combat task. The obtained results give grounds to conclude that the implementation of the recommendations will reduce the time for calculations to $25 \%$, as well as an increase to $10 \%$ the number of possible options for creating a system of engineering barriers.

Keywords: the system of engineering barriers, defense, the efficiency of engineering barriers, specialized software, the planning process. 